\title{
A NEW SPECIES FROM TASMANIA OF THE FRESHWATER HOPLONEMERTEAN, POTAMONEMERTES
}

\author{
by J.L. Hickman and J.Moore \\ (with two tables and five plates)
}

HICKMAN, J.L. \& MOORE, J.. 199() (31:x): A new species from Tasmania of the freshwater hoplonemertean.

Potamonemertes. Pap. Proc. R. Soc. Tasm. 124(1): 51-59. https://doi.org/10.26749/rstpp.124.1.51

ISSN (0)8()-47()3. Department of Zoology, Unversity of Tasmania, GPO Box 252C, Hobart, Tasmania, Australia 7()()1 (JLH); and Department of Zoology, Dow ning Street, Cambridge CB2 3EJ. England (JM).

A new species of freshwater hoplonemertean, Potamonemertes gibsoni, is described from lakes in Tasmania and its relationship to the type species from New Zealand and to the terrestrial nemerteans of the region is discussed. Key Words: ireshwater, nemerteans, Potamonemertes, Tasmania.

\section{INTRODUCTION}

All known freshwater hoplonemerteans belong either to the genus Prostoma Dugès 1828 (family Tetrastemmidae) or to the monotypic genera more recently described from New Zealand, Potamonemertes Moore \& Gibson 1973 and Campbellonemertes Moore \& Gibson 1972. These New Zealand genera are very different from Prostoma and have been placed in the same family as the terrestrial nemerteans of New Zealand and Australia, which they closely resemble (Gibson \& Moore 1976). Fulton (1983) reported the finding of a nemertean in Great Lake, Arthurs Lake and Lake Sorell, in central Tasmania. The present paper identifies this form as a new species of Potamonemerte's to be named $P$. gibsoni in tribute to Professor Ray Gibson, Liverpool Polytechnic, England. Since the genus Potamonemertes was previously known only from the New Zealand type species, $P$. percivali Moore \& Gibson 1973, it is particularly interesting that another species has been found in Tasmania. This paper describes the new species and also considers the distribution of the genus and its relationship to the terrestrial nemerteans of the region.

\section{MATERIALS AND METHODS}

Samples were collected between 1975 and 1978 from the floor of Great Lake (11 to $17.5 \mathrm{~m})$ and Arthurs Lake ( 6.5 to $14 \mathrm{~m}$ ) on the Central Plateau, using an Ekman grab of $2.32 \mathrm{~cm}^{2}$ gape (Fulton 1983). The samples were then sieved $(0.7 \mathrm{~mm}$ mesh size) and the animals retained by the sieve were preserved in 70\% ethanol: some were fixed in Clarke's fixative prior to preservation. The samples were subsequently found to include nemerteans, wh ich were presented to JLH for identification. In total 19 preserved specimens were received and also 11 live nemerteans: these were fixed in hot Susa's fixative, rinsed in iodised $70 \%$ ethanol and preserved in $90 \%$ ethanol. Twenty-five of the specimens were sectioned at $10 \mathrm{~mm}$ and stained in Ehrlich's haematoxylin and eosin. Three specimens were stained in Mallory's triple stain by JM, to facilitate comparison with similarly stained sections of Potamonemertes percivali. Fulton (1983) also records the finding of the nemertean in Lake Sorell, Central Plateau, in 1981, and in 1987 further specimens were obtained (using a surber sampler, $500 \mathrm{~mm}$ mesh) from the sandy gravel of the Giblin River on the southwestern coast of Tasmania and from Giblin Bay in Lake Pedder -... both sites being within the Tasmanian Wilderness World Heritage Area. These were given to JM, sectioned and stained in Mallory's triple stain, and added to the Pantin Collection.

\section{POTAMONEMERTES GIBSONI SP.NOV.}

Type Material

(letters in parentheses refer to slide series)

\section{Holotype}

Arthurs Lake (West Lake north), 23/7/77, W. Fulton, T.S., 20 slides (S). Tasmanian Museum, Hobart Reg. No. K1135. 


\section{Paratypes}

Arthurs Lake, 4.iv.77, T.S. 10 slides (H). Pantin collection, British Museum (Nat. Hist.), London (at present in the care of JM at the Zoology Department, Cambridge). Great Lake (Cramps Bay), 4.xii.75, T.S. 19 slides (E); Arthurs Lake (East Lake south), 10.x.77, L.S. 10 slides (0); Arthurs Lake (East Lake north), 24.i.77, H.S., 3 slides (W); Great Lake (Brandum Bay), 2.vi.75, H.S. 5 slides (BB); Arthurs Lake (Tea-tree Bay), 28.xi.77, H.S. 9 slides (EE).

Tasmanian Museum, Hobart Reg. Nos. K1136 (T.S. 19 slides); K1137 (L.S. 10 slides); K1138 (H.S. 3 slides); K.1139 (H.S. 5 slides); K1140 (H.S. 9 slides)

\section{Distribution}

The species has been recorded only from Tasmania. It has been found on the Central Plateau at Arthurs Lake, Great Lake and Lake Sorell; and in the Tasmanian Wilderness World Heritage Area at
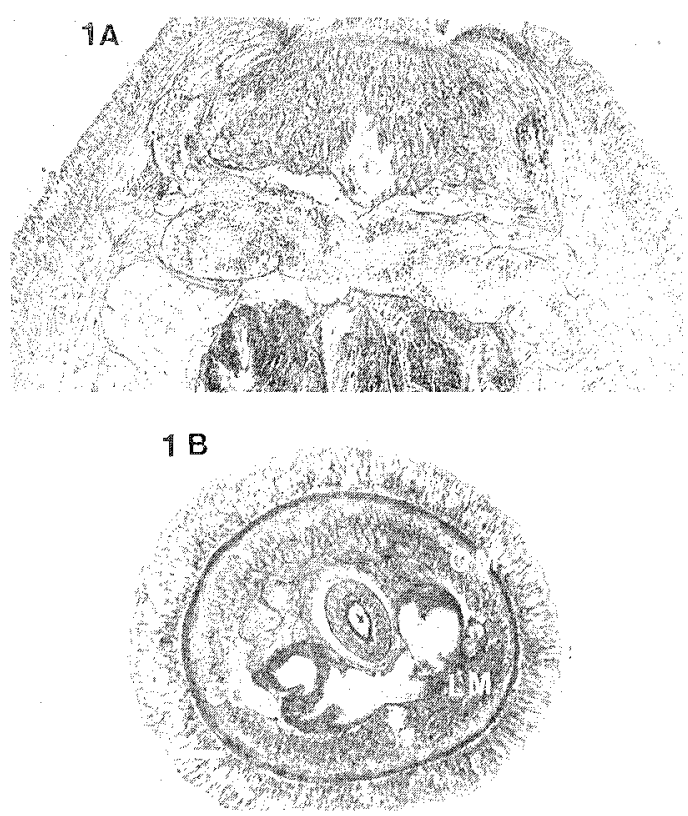

PLATE $I$

Potamonemertes gibsoni sp.nov. (A) LS anterior region; $(B) T S$ brain region. Showing the relative thickness of circular muscle (CM) and longitudinal muscle (LM), the ventral cerebral commisure (VC) and the posterior extent of the cephalic gland (CG). Scale bar $=500 \mu \mathrm{m}$ for both.
Giblin River on the southwestern coast and Giblin Bay in Lake Pedder.

\section{Appearance in Life and Behaviour}

The specimens were pale red to white in colour and small, attaining a maximum length of $20 \mathrm{~mm}$. Spontaneous fragmentation was pronounced. This phenomenon has been observed in certain terrestrial nemerteans when in poor condition, and recorded from the Australian terrestrial nemertean Argonemertes stocki which shows controlled fragmentation of the posterior end into millimetre cubes (Moore 1975), but has not been recorded from any freshwater nemertean other than Potamonemertes percivali. Percival in 1943 recorded that "The animals were difficult to take whole, as they fragmented quickly and easily" (pers. comm. to Dr C.F.A. Pantin). This also was the experience of JM on revisiting Percival's type locality in January 1988 to observe $P$. percivali.

\section{Anatomy}

The general morphology of the present specimens is similar to that described by Moore \& Gibson (1973) for Potamonemertes percivali. A full anatomical description is thus unnecessary. In the following brief account emphasis is given to characters significant in the taxonomy of related genera and to points of comparison with $P$. percivali.

Measurements made on the histological preparations are recorded where relative values may be interesting. However, living specimens were up to $20 \mathrm{~mm}$ in length while preserved mature specimens ranged from 2.5 to $8 \mathrm{~mm}$. Such shrinkage is usual in nemerteans which have not been narcotised before preservation, and may occur unevenly.

\section{Body Wall}

The body is covered by a thick $(35-80 \mathrm{~mm})$ ciliated epidermis including gland cells. The underlying dermis, composed of connective tissue, is relatively thick $(5-13 \mathrm{~mm})$. The musculature is (as in $P$. percivali) particularly well developed for a small nemertean, most especially in the anterior part of the body. Whereas in $P$. percivali the two muscle layers are approximately equal in thickness, in the present specimens the longitudinal muscle layer of the anterior region $(12.5-137 \mathrm{~mm})$ is considerably thicker than the circular muscle $(5-25 \mathrm{~mm})$ (pl. $1 \mathrm{~A}, \mathrm{~B})$. 


\section{Parenchyma}

Parenchyma is fairly extensive in most parts of the body posterior to the pyloric region.

\section{Rhynchocoel}

This is "full body length", i.e. extends to within 100 to $500 \mathrm{~mm}$ of the posterior tip of the body. Its muscular wall can be described as a single layer composed of circular, longitudinal and oblique fibres: it is constructed as a wickerwork of circular and longitudinal muscle fibres as is characteristic also of the Australian and New Zealand land nemerteans and other related forms. According to Gibson (1988) this character state defines a major subdivision of the hoplonemerteans, the Paramonostilifera (pls 2A, 5A).

\section{Proboscis}

This is very large, being approximately $1 / 2$ to $3 / 4$ the length and $1 / 5$ to $1 / 3$ the diameter of the worm. Everted, it measures $3 / 4$ to $11 / 3$ the length and $1 / 3$ to $2 / 3$ the diameter of the worm. The anterior proboscis consists of the usual layers, without muscle crosses and without enclosure of circular muscles in the dermis. There are 12-18 proboscis nerves. The stylet region includes 2-4 accessory stylet sacs each containing 3-7 stylets which measure $60-87 \mathrm{~mm}$ in length and $15-20 \mathrm{~mm}$ in diameter at their base. Unlike $P$. percivali each accessory sac has a duct which opens near the base of the main stylet (pl. 2B). The main stylet measures $43-70 \mathrm{~mm}$ in length and $13-20 \mu \mathrm{m}$ in diameter at its base. The basis is urn shaped $65 \times 42.5-126 \times 78 \mathrm{~mm}$.

\section{Gut}

The gut is typical: the oesophagus is a short unciliated tube leading from the rhynchodeum into the large glandular stomach (approximately $1 / 10$ the length of the worm) which extends posteriorly as a wide dorsoventrally flattened pyloric tube (1/6 to $1 / 17$ the length of the worm) leading to the intestine. From the point where the pylorus joins the intestine a ventral caecum extends anteriorly, ventral to the pylorus, and bifurcates into blind diverticula $100-350 \mathrm{~mm}$ long, which extend forwards to the brain.

\section{Eyes}

Eyes are absent. This character state is shared by $P$. percivali, Campbellonemertes, one species of
Prostoma and all known freshwater heteronemerteans. Most marine and all known terrestrial nemerteans possess eyes.

\section{Cerebral Organs}

As in $P$. percivali these open laterally from short longitudinal epidermal furrows. However, they are much larger and have a different shape. The cercbral canal passes posteroventrally from the furrow for $100-125 \mathrm{~mm}$ to enter the ganglionic mass which is ovoid $(60 \times 62-100 \times 125 \mathrm{~mm})$ and situated anterolateral to the ventral cerebral ganglion. Within the mass the canal passes round to the ventral and inner posterior region where it ends blindly among the cerebral gland cells. Although the canal does not fork, in some sections a very small dorsal diverticulum appears to be present where the canal enters the ganglionic mass. The cerebral gland cells extend backwards for $110-200 \mathrm{~mm}$ along the ventro-lateral aspect of the dorsal cerebral ganglion to nearly level
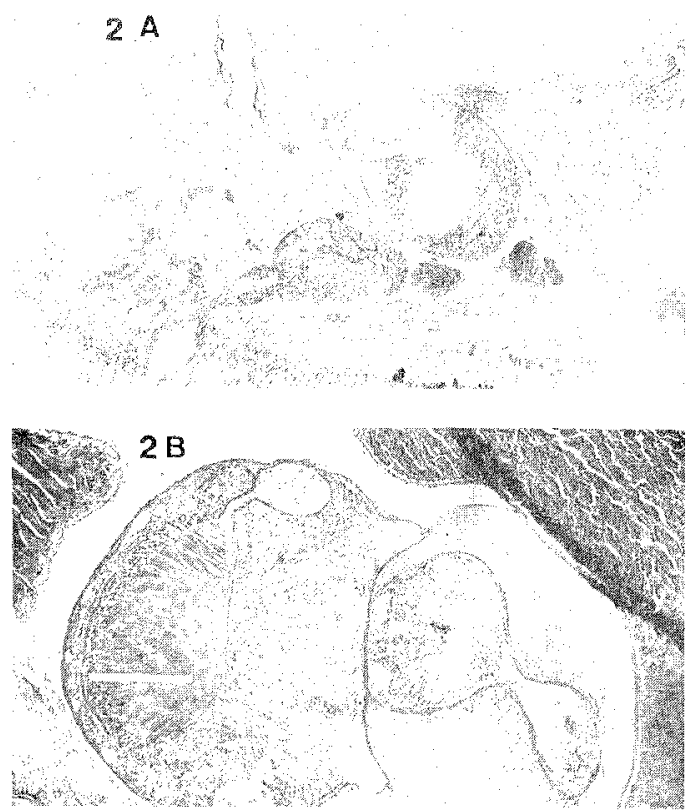

\section{PLATE 2}

Potamonemertes gibsoni sp. nov. (A) LS to show the cerebrat organ: the cerebral canal opening $(\mathrm{O})$ and the ganglionic region $(\mathrm{G})$ beside the ventral cerebral ganglion (VG) are evident; the wickerwork structure of the rhynchocoel wall musculature (RM) is also shown. (B) Stylet region of proboscis to show' an accessory stylet sac (ASS) with dact. Scale bar = 100 um for both. 

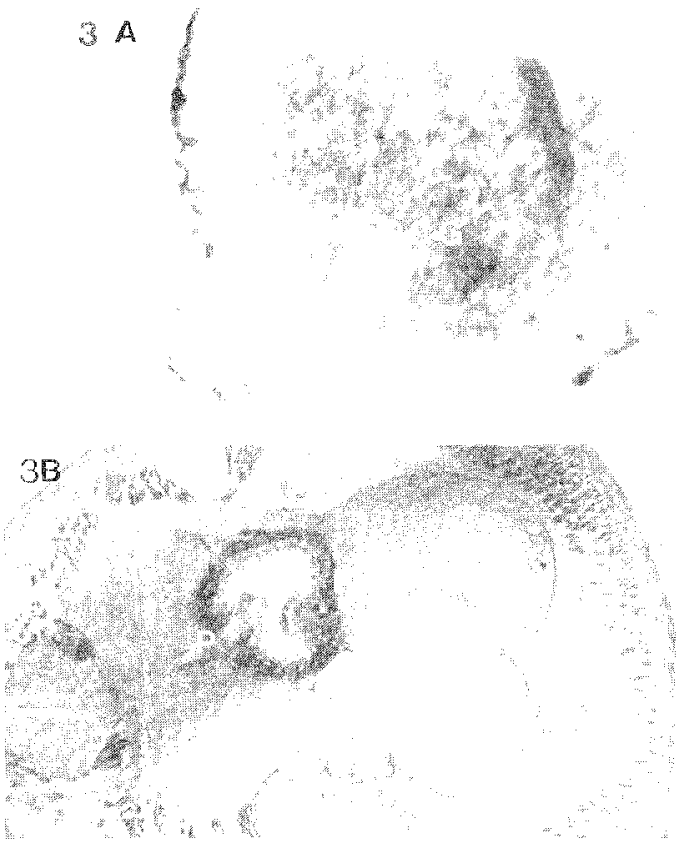

PLATE 3

Potamonemertes gibsoni $s p$. nov. (A) LS anterior end to show the discharge of the cephalic glands (CG) into the frontal organ ( $\mathrm{FO})$; scale bar $=50 \mathrm{\mu m}$. (B) TS brain region to show the two vascular plugs (P) and the posterior extent of the cephalic gland (CG); scale bar $=200 \mu \mathrm{m}$.

with the posterior margin. The cerebral gland has a maximum diameter $(40-75 \mathrm{~mm})$ where it adjoins the ganglionic mass (pl. 2A).

\section{Frontal Organ}

There is a small but distinct frontal organ, $50-80 \mathrm{~mm}$ in diameter, through which the cephalic glands discharge (pl. 3A). The organ opens into a cavity approximately $15 \mathrm{~mm}$ in diameter and $30 \mathrm{~mm}$ in depth. In P. percivali the frontal organ and cephalic glands are described as having separate openings.

\section{Cephalic Gland}

This is considerably larger than in P. percivali where it is restricted to a small anterior dorsal cap. In the new species, the gland consisting solely of basophilic lobules) extends back, 2/2-464 mm, as far as the posterior surface of the dorsal cerebral ganglion (pls 1B, 3B).
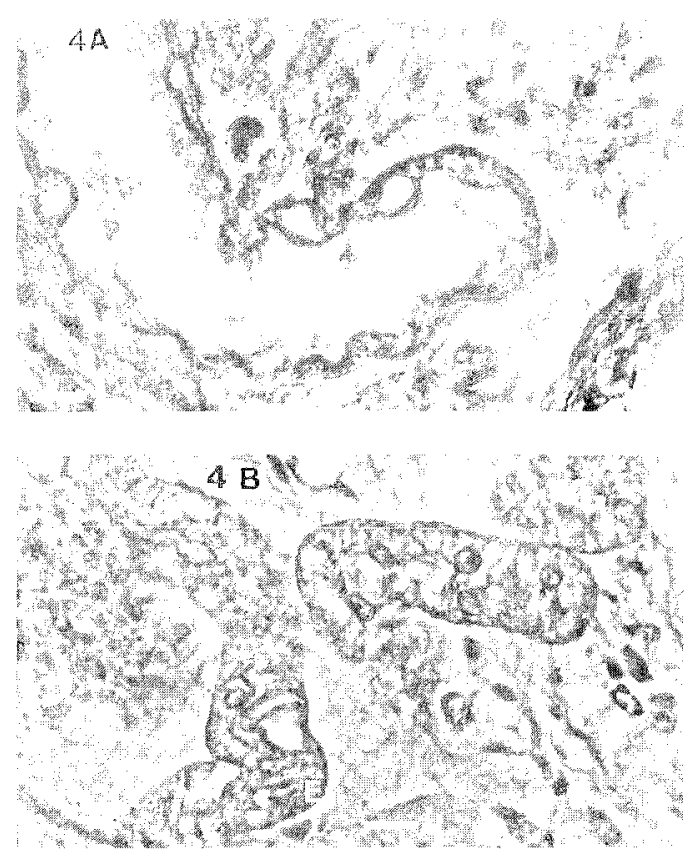

PLATE 4

Potamonemertes gibsoni $s p$. nov. (A) Lateral blood versel (BV) to show valves in the wall. (B)Excretory ducts (E) and flame cells (F). Scale bar $=30 \mu \mathrm{m}$ for both.

\section{Nervous System}

The nervous system is typical of hoplonemerteans but lacks the posterior protuberances on the ventral cerebral commissure which constitute a unique feature of $P$. percivali: this must therefore be seen as a specific raiher than a generic specialisation. The present specimens resemble $P$. percivali in having no neurochord cells, no accessory lateral nerve and no dorsal contribution to the lateral nerve from the dorsal cerebral ganglion.

\section{Vascular System}

As in $P$. percicali and all other known freshwater nemerteans, the only cross-connections present between the dorsal and lateral blood vessels are the cephalic loop, which passes through the cephalic gland, and the supra-anal commissure. Accordingly the two vascular plugs are borne on the lateral vessels, anterior to the origin (from one lateral 
vessel of the mid-dorsal vessel. The plugs (about $70 \mathrm{~mm}$ in duncter) project into the rhynchocoel in the cerebral region (pl. 3B). The lateral vessets, as in $P$. percilali are lacumar but smaller, and valves (rare in $P$. protali) we evident in the blood vessels of the present spechems (p. 4A).

\section{Excrelory System}

The excucusy system does not differ from that of $P$. pertivali it is very well developed and extends throughout the animal. Simple paired mononucleate flame cells led into excretory ducts which open by a very large number of small pores. The excrelory ducts are thick walled with the specialised structure unique to Australian and New Zealand terrestrial nemerteans and Potamoncmertes (pls 4B, 5A).

\section{Gonads}

The animals are simultaneously hermaphroditic and probably also variably protandrous. As in $P$. percivali, the testes generally extend further forward than the ovaries, however, there is no sharp separation of the testicular from the ovarian field. Testes may occasionally occur as far forward as the brain but more commonly extend posteriorly from the region of the pyloric lube, being dorsal, lateral and ventral in position (pl. 5B). The maximum dimension of mature testes varies from 125-192 mm and that of mature ovaries from $230-272 \mathrm{~mm}$. Ripe ova ineasure 224-272 $\mathrm{mm}$ and have nuclei $56-64 \mathrm{~mm}$ in diameter.

\section{GENERIC DIAGNOSIS AND SPECIFIC DIFFERENCES}

Now that a second species of Potamonemertes has been described, a generic diagnosis can be given and the specific differences between the type species from New Zealand, $P$. percivali, and the present Tasmanian species, $P$ gibsoni, can be tabulated.

\section{Potamonemertes Moore \& Gibson 1973}

\section{Diagnosis}

Freshwater Paramonoslilifera with body wall musculature particularly well developed in anterior portion of body; epidemis typical, dermis thick, parenchyma extensive in most of body; thynchocoel full body length with wall composed of wickerwork of interwoven circular, oblique and longitudinal

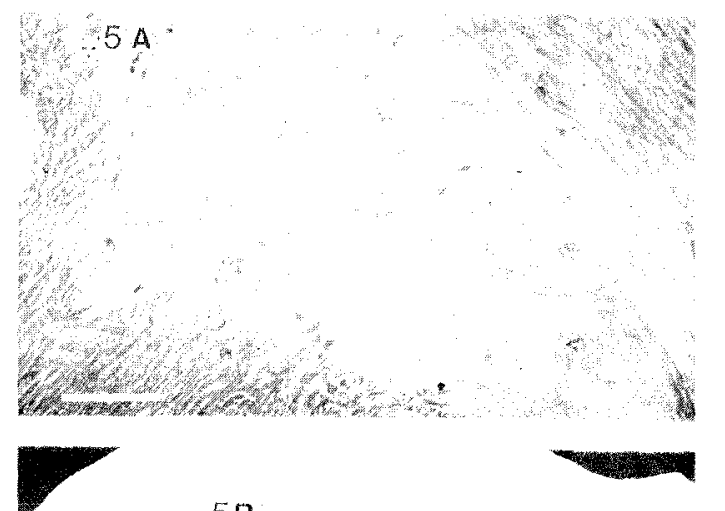

$5 B$

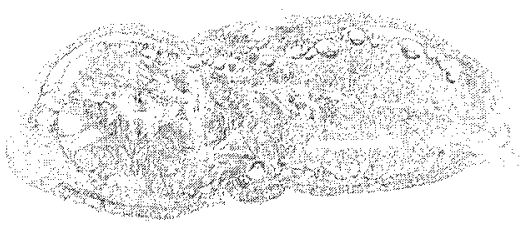

PLATE 5

Potamonemertes gibsoni sp. nov. (A) Excretory ducts ( $\mathrm{E})$, flame cells $(\mathrm{F})$ and rhynchocoel musculature (RM); scale bar $=100 \mu m$. (B) LS to show the position of the gonads: ovaries( $\mathrm{O})$, testes (T); scale bar $=1000 \mu \mathrm{m}$.

muscle fibres; proboscis massive and at least as long as the body; alimentary canal with mid-ventral caecum bearing anterior diverticula; eyes absent; cerebral organs anterior, with canal unforked and no anterior sac, opening into a pair of lateral longitudinal cephalic furrows, frontal organ present, cephalic gland opening to the exterior through a single pore which is either the frontal organ or a small median pore dorsal to it; nervous system with no neurochord cells, no accessory lateral nerve and no contribution from the dorsal cerebral ganglion to the lateral nerve; blood vascular system with lacunar lateral vessels and mid-dorsal vessel arising from one of them post cerebrally, these vessels having no commissural connection other than the cephalic vascular loop and the supra-anal commissure; two vascular plugs, borne on the two lateral vessels, projecting into the rhynchocoel in the cerebral region; excretory system extending throughout body consisting of simple paired mononucleate flame cells and excretory ducts opening by numerous pores, these ducts being thick walled specialised structures; hermaphrodite, simultaneous, and 
probably variably protandrous, gonads either sharply regionalised or overlapping with testes at least extending further forward than ovaries; readily fragmen $\mathbf{t}$.

\section{FAMILIAL PLACING OF POTAMONEMERTES}

Potamonemertes and Campbellonemertes were originally placed in the family Prosorhochmidae, with the undivided genus Geonemertes (Moore \& Gibson 1972, 1973). Further information about the convergent origin of terrestrial nemerteans led to the splitting of the genus Geonemertes (Moore \& Gibson 1981) and the recognition of two distinct groups of land nemerteans. Redescription of the genus Prosorhochmus (Gibson \& Moore 1985) established that only the first group of land nemerteans (the redefined genus Geonemertes, and Pantinonemertes) should remain in the Prosorhochmidae. Potamonemertes and Campbellonemertes belong with the Australian terrestrial genus Argonemertes, the New Zealand terrestrial genus Antiponemertes, and Acteonemertes in the newly erected family Plectonemertidae (Moore \& Gibson 1988) which includes forms with wickerwork rhynchocoel musculature, two vascular plugs and other uniting characters (see table 1).

\section{DISCUSSION}

We now have further knowledge of the distribution of Potamonemertes and a better basis for distinguishing the generic from the specific characters. Do we, however, have further clues to its evolutionary history? That species of the same freshwater genus should occur both in New Zealand and in Tasmania is not unusual, being known to occur, for example, in the following genera, Coleoptera: Hydraena, Meropathus; Crustacea: Boeckella; Mollusca: Gyraulus, Physastra, Sphaerium; Platyhelminthes: Temnocephala, Cura. While Potamonemertes is known only from New Zealand and Tasmania, and Campbellonemertes only from one species on Campbell lsland, the other freshwater hoplonemertean genus, Prostoma, is worldwide in distribution. In many countries details of its occurrence are unknown: in Tasmania it appears only to occur in areas which have been settled at one time or another by Europeans, suggesting that it may have been introduced. Both Potamonemertes and Camphellonemertes resemble the terrestrial nemertines of New Zealand (the genus
Antiponemertes, and the upper littoral/terrestrial genus Acteonemertes) and Australia (the genus Argonemertes) in morphology as well as geographical distribution (see table 1). Potamonemertes and Campbellonemertes are unlike terrestrial nemerteans and resemble each other in the rather mysterious "freshwater features" concerning absence of eyes, absence of cross connections between the longitudinal blood vessels and being hermaphroditic (but Argonemertes dendyi is one terrestrial nemertean which also is hermaphroditic). Absence of eyes in freshwater forms may be indicative of the animals living within the organic debris and silt in the bed of the stream, pond or lake. Similarly among the terrestrial turbellarians, eyes are extremely well developed along the lateral margin of the rather flat body of those species which feed on the surface inhabiting fauna. During the day they can be found in crevices in logs or under logs, stones and litter. They probably use their eyes to detect (among other things) the light intensity gradient within which they can safely move and feed. A few species are blind and during the day are found in cavities under stones and logs. These may well feed on fauna below the surface, in cavities such as burrows or tunnels in the ground or in logs. Apart from the "freshwater features" Potamonemertes and Camphellonemertes do not seem to be particularly closely related within the family: Campbellonemertes is quite different in size and shape and has a great many specialisations. It is Potamonemertes which more closely resembles terrestrial nemerteans, in particular in having a very large proboscis and the specialisation of the excretory ducts which is otherwise unique to Argonemertes and Antiponemertes.

Moore \& Gibson (1973) built on this resemblance to postulate an evolutionary sequence: they suggested that Potamonemertes may have colonised freshwater by way of the land. The points of resemblance are functionally appropriate for terrestrial nemerteans, for example a greatly enlarged proboscis which is used for quick escape movements is almost universal among terrestrial nemerteans of both families (Prosorhochmidae and Plectonemertidae). Further, in contrast to Prostoma, Potamonemertes and Campbellonemertes belong to a family with no known estuarine species. However, this hypothesis is not supported by cladistic analysis (Sundberg 1989) and must remain in doubt. Some marine features which Potamonemertes has retained which conceivably would have been modified had its progenitors been terrestrial are: (a) the lateral longitudinal furrows into which the cerebral organs open; (b) the presence of a frontal organ; (c) the 
TABLE 1

Comparison of Potamonemertes with Australian Land and Freshwater Genera and with Prostoma

\begin{tabular}{|c|c|c|c|c|c|c|}
\hline & $\begin{array}{c}\text { Acteo- } \\
\text { nemertes }\end{array}$ & $\begin{array}{l}\text { Antipo- } \\
\text { nemertes }\end{array}$ & $\begin{array}{c}\text { Argo- } \\
\text { nemertes }\end{array}$ & $\begin{array}{l}\text { Potamo- } \\
\text { nemertes }\end{array}$ & $\begin{array}{l}\text { Campbello- } \\
\text { nemertes }\end{array}$ & Prostoma \\
\hline \multicolumn{7}{|l|}{ Rhynchocoel musculature: } \\
\hline \multicolumn{7}{|l|}{ Rhynchocoel full body } \\
\hline length $(+)$, much shorter $(0)$ & + & + & + & + & + & 0 \\
\hline Number of vascular plugs & 2 & 2 & 2 & 2 & 2 & 1 \\
\hline $\begin{array}{l}\text { Body musculature well developed } \\
\text { with thick dermis }(+) \text { not so }(0)\end{array}$ & + & + & +0 & $t$ & t & 0 \\
\hline $\begin{array}{l}\text { Parenchyma extensive }(+), \\
\text { sparse }(0)\end{array}$ & + & + & + & + & + & 0 \\
\hline $\begin{array}{l}\text { Proboscis large, active in loco- } \\
\text { motion }(+) \text {, not so }(0)\end{array}$ & + & + & + & + ? & 0 & 0 \\
\hline $\begin{array}{l}\text { Gut with pyloric tube and ventral } \\
\text { caecum }(+) \text {, without }(0)\end{array}$ & + & + & + & + & + & 0 \\
\hline Anterior caecal diverticula & & & & & & \\
\hline long $(++)$, short, variable $(+)$ & ++ & + & ++ & + & + & ++ \\
\hline Frontal organ present $(+)$, absent $(0)$ & 0 & 0 & 0 & + & 0 & + \\
\hline $\begin{array}{l}\text { Cephalic gland opens into frontal } \\
\text { organ or nearby duct }(+) \text { or into } \\
\text { improvised openings }(0)\end{array}$ & 0 & 0 & 0 & + & 0 & + \\
\hline Cephalic gland very extensive $(++)$ & & & & & & \\
\hline fairly extensive $(+)$, restricted $(0)$ & ++ & ++ & ++ & +0 & ++ & +0 \\
\hline $\begin{array}{l}\text { Cerebral organ large with forked } \\
\text { canal }(++) \text { unique specialization }(+) \text {, } \\
\text { smaller and simple }(0)\end{array}$ & 0 & ++ & ++ & 0 & + & 0 \\
\hline $\begin{array}{l}\text { Multiplication of excretory ducts } \\
\text { and pores very great }(++), \\
\text { slight }(+)\end{array}$ & t+ & ++ & ++ & ++ & ++ & + \\
\hline $\begin{array}{l}\text { Excretory ducts with specialised } \\
\text { region }(+) \text {, uniform }(0)\end{array}$ & 0 & + & + & + & 0 & 0 \\
\hline Habitat:Upper littoral (UL), & & & & & & \\
\hline Terrestrial (T), Freshwater(FW) & $\mathrm{UL}$ & $\mathrm{T}$ & $\mathrm{T}$ & FW & FW & FW \\
\hline Number of eyes & $4-6$ & $2-4$ & $20-180$ & 0 & 0 & $0-6$ \\
\hline $\begin{array}{l}\text { Cerebral organ opens into lateral long- } \\
\text { itudinal furrows }(0) \text {, single } \\
\text { ventral transverse furrow }(+)\end{array}$ & + & + & + & 0 & 0 & 0 \\
\hline $\begin{array}{l}\text { Blood vessels with capillary net } \\
\text { work extensive }(+) \text {, without } \\
\text { cross links between cephalic \& } \\
\text { and region }(0)\end{array}$ & + & + & + & 0 & 0 & 0 \\
\hline Gonads: hermaph. $(+)$, single sex $(0)$ & 0 & 0 & $0+$ & + & + & + \\
\hline
\end{tabular}


cephalic gland opening confluent with the frontal organ and (d) the rather limited development of the cephatic gland. Other features, however, are suggestive of a prior terrestrial existence, for example, (a) the multiplication of excretory ducts;

(b) the regional specialisation of the excretory ducts;

(c) the small size of the frontal orgitn and (d) the relatively large proboscis. Whatever the evolutionary sequence, there is no doubt that Potamonemertes and Campbellonemertes are closely related to the land nemerteans of Australia and New Zealand and are far removed from Prostoma which originated elsewhere.

Comparison of the two species of Potamonemertes (table 2) shows that in every point of difterence it is the Tasmanian species, P. gibsoni, which is less specialised. The ventral cerebral commissure is normal in form, as are the body wall muscle, oesophagus, blood vessels and stylet region. The unusual regional division of the gonads is less marked in $P$. gibsoni. Possession of a frontal organ (by both species) is a common feature of marine nemerteans but is in strong contrast to the less restricted outlet for the mucus secretion found in terrestrial forms in the Plectonemertidae (presum ably reflecting the greater demand for copious mucus secretion in the terrestrial forms). The amount of cephalic gland present in $P$. gibsoni is nearer to that of the rerresirial genera. Of the two species, then, it is the Tasmanian one which more closely tesembles both the terrestriat nenerines and their marine relatives. Whather the ancestors of Potamonemertes colonised rreshwater directly (up rivers) or by an overkand route (thus requiring them to first become completely terrestrial) or via lagoons and swamps (the conditions of which lluctuated in such a way as to favour the emergence of some terrestrial preadaptation but also an adaptation to freshwater), it is tempting to suppose that this mignt have happened in Australia rather than New Zealand, $1 \mathrm{t}$ is hard to decide whether Potamonemertes is closer to Argonemertes or Antiponemertes: these two genera differ primarily in the number of eyes, and Potamonemertes has none. Differences between Argonemertes and Antiponemertes concerning the size of the posterior gland of the cerebral organ, the mobility of the stomach and the relative length of the anterior caecal

TABLE 2

Differences Between the Two Known Species of Potamonemertes

\begin{tabular}{|c|c|c|}
\hline & $P \cdot$ percivali & P. gibsoni \\
\hline Sites of occurrence & $\begin{array}{l}\text { New Zealand: } \\
\text { Coe's Ford, Selwyn } \\
\text { River, Canterbury }\end{array}$ & $\begin{array}{l}\text { Tasmania: } \\
\text { Great Lake, Arthurs Lake, } \\
\text { Lake Sorell, Lake Pedder, } \\
\text { Giblin River }\end{array}$ \\
\hline Ventral cerebral commissure & With posterior protuberances & $\begin{array}{l}\text { Normal, i.e without posterior } \\
\text { protuberances }\end{array}$ \\
\hline Cephalic gland & $\begin{array}{l}\text { Small dorsal/anterior } \\
\text { cap only. Opens by separate } \\
\text { pore dorsal to frontal organ }\end{array}$ & $\begin{array}{l}\text { Extends from anterior to brain } \\
\text { region. Opens through frontal } \\
\text { organ }\end{array}$ \\
\hline Cerebral organ & $\begin{array}{l}\text { Ganglionic mass elongate and small, } \\
\text { less than one third of the size of the } \\
\text { ventral cerebral ganglion; gland short }\end{array}$ & $\begin{array}{l}\text { Ganglionic mass compact nearly } \\
\text { spherical and nearly as large as } \\
\text { ventral cerebral ganglion; gland } \\
\text { elongated }\end{array}$ \\
\hline Ocsophagus & Ciliated & Unciliated \\
\hline Body wall muscle & $\begin{array}{l}\text { Longitudinal and circular } \\
\text { layers equally well developed }\end{array}$ & $\begin{array}{l}\text { Longitudinal muscle layer } \\
\text { much thicker than circular in } \\
\text { anterior part of body }\end{array}$ \\
\hline Blood vessels & $\begin{array}{l}\text { Very large lacunae } \\
\text { Valves rare }\end{array}$ & $\begin{array}{l}\text { Moderate sized lacunae } \\
\text { Valves common }\end{array}$ \\
\hline Stylet region & $\begin{array}{l}\text { No canals between accessory } \\
\text { sacs and main stylet }\end{array}$ & Canals present \\
\hline Gonad distribution & Sharply regionalised & $\begin{array}{l}\text { Testes and ovaries cxtensively } \\
\text { overlap }\end{array}$ \\
\hline
\end{tabular}


diverticula are not sufficiently marked for any hypothesis. The two terrestrial genera are distinctly different in behaviour (Moore 1989) but this is no help. All that can be said is that the New Zealand species of Potamonemertes has more secondary specialisations than the Tasmanian one.

\section{ACKNOWLEDGEMENTS}

We should like to thank W. Fulton, Tasmanian Inland Fisheries Commission, for providing the specimens, and Newnham College, Cambridge, for the award of the Phyllis and Eileen Gibbs Travelling Fellowship which made possible the visit of JM to Tasmania and New Zealand.

\section{REFERENCES}

Fulron, W., 1983: Macrobenthic fauna of Great Lake, Arthurs Lake and Lake Sorell, Tasmania. Aust. $J$. Mar. Freshw. Res. 34: 775-85.

Gibson, R., 1988: Evolutionary relationships between mono- and polystiliferous hoplonemerteans. Hydrobiologica 156: 61-74.
Gibson, R. \& Moore, J., 1976: Freshwater nemerteans. Zool. J. Linn. Soc. 58: 177-218.

Gibson, R. \& Moore, J., 1985: The genus Prosorhochmus Keferstein 1862 (Hoplonemertea). J. Zool. Lond (A) 206: 145-162.

Moore, J., 1975: Land nemertines of Australia. Zool. I. Linn. Soc. 56: 23-43.

Moore, J, 1989: A record of the behaviour and distribution of New Zealand land nemertines. N.Z.Nutural Sciences 16: 79-86.

MOORE, J. \& Gibson, R., 1972: On a new genus of freshwater hoplonemertean from Campbell lsland. Freshw. Biol. 2: 187-203.

Moore, J. \& Grison, R., 1973: A new genus of freshwater hoplonemerteans from New Zealand. Zool. $J$. Linn. Soc. 52: 141-157.

Moore, J. \& Gibson, R., 1981: The Geonemertes problem (Nemertea). J. Zool. Lond. 194: 175-20 I.

MOORE, J. \& Gibson, R., 1988: Further studies on the evolution of land and freshwater nemerteans: generic relationships among paramonostiliferous taxa. J. Zool. Lond. (A) 216:1-20.

Sundberg, P., 1989: Phylogeny and cladistic classification of the paramonostiliferous family Plectonemertidae (phylum Nemertea). Cladistics 5: $87-100$.

(accepted 15 April 1990) 